\title{
Reptilian Mycophagy: A global review of mutually beneficial associations between reptiles and macrofungi
}

\author{
Elliott TF* ${ }^{*}$ Bower DS and Vernes $\mathrm{K}$
}

Ecosystem Management, University of New England, Armidale, NSW 2351, Australia

Elliott TF, Bower DS, Vernes K 2019 - Reptilian Mycophagy: A global review of mutually beneficial associations between reptiles and macrofungi. Mycosphere 10(1), 776-797, Doi 10.5943/mycosphere/10/1/18

\begin{abstract}
Macrofungi are an important food source for many mammals, birds and arthropods; in return, these animals disperse numerous species of fungi through their scats. Many of the fungi that are important as food also perform key functions in the ecosystem through nutrient cycling. Research on associations between reptiles and fungi has primarily focused on pathology and has mostly overlooked mutually beneficial relationships between these two groups of organisms and the positive impacts of their associations on overall ecosystem health. There is a substantial body of disparate research showing the importance of turtles as seed dispersers, but we provide the first study evaluating the ecological implications of turtles and other reptiles as macrofungi spore dispersers. These associations have been less thoroughly studied than those between mammals and fungi, yet we show that they have similar ecological importance. In this review, we present the most comprehensive summary to date of reptile species reported to eat fungi (42 reptile species in 7 families) and outline the potential importance of reptiles as spore dispersers for fungi that play a positive role in ecosystem dynamics. We also show that oversights in the methodology of past dietary studies may have led to false representation of the role of fungi in reptile diets, and we make recommendations for future dietary studies involving reptiles.
\end{abstract}

Key words - fungal dispersal - fungivory - mycorrhizae - reptile nutrition - spore dispersal

\section{Introduction}

In recent years, most collaborations between mycologists and herpetologists have primarily focused on conservation issues surrounding the spread of the pathogenic chytrid fungi Batrachochytrium spp. (Fisher et al. 2009, Martel et al. 2013). The associated disease, chytridiomycosis, has caused major conservation tragedies for amphibians in South America, Australia and Europe (Scheele et al. 2019) and demonstrates how virulent and effective some groups of fungi can be at global dispersal.

Most species of fungi are fortunately not harmful to reptiles and amphibians and are actually beneficial to their biology. Many fungi are nutritionally important for lizards and turtles (Carr 1952, Cooper \& Vernes 2011, Wanchai 2012), and at least two snake species (Leptodeira annulata and Liotyphlops albirostris) utilise the fungus gardens of the neo-tropical leaf-cutter ants (Apterostigma spp. and Atta spp.) as safe incubation/nursery chambers for their eggs (Baer et al. 2009, Bruner et al. 2012). 
Globally, fungi fulfill a plethora of ecological functions. Saprophytic fungi are vital to the cycling of organic woody material like cellulose and lignin, the majority of vascular plants depend on symbiotic mycorrhizal fungi to extract water and minerals from their environment, and fungal pathogens are continually creating disturbances that contribute to a functional ecosystem (Peay et al. 2008, Smith \& Read 2008, Tedersoo et al. 2010, Elliott \& Stephenson 2018). These are just a few examples of the ecological roles played by fungi; yet without various modes of dispersal, fungi cannot spread between and through ecosystems fulfilling these functions. Thus, fungal spore dispersal is key to maintaining ecosystem health. Fungi have evolved a multitude of mechanisms to disperse spores, but dispersal by animals through consumption and excretion is one of the most effective (Gehring et al. 2002, Danks 2011, Nuñez et al. 2013, Horton 2017). Fungal spores remain viable after passage through the digestive tracts of vertebrates (Trappe \& Maser 1976, Kotter \& Farentinos 1984, Lamont et al. 1985, Claridge et al. 1992, Colgan \& Claridge 2002, Caldwell et al. 2005, Piattoni et al. 2014, Ori et al. 2018) and can thus be dispersed as far as the animal who ate them travels.

The importance of animals as fungal spore dispersers depends on the fruiting morphology of a given group of fungi. Some fungi, such as the puffball genus Bovista and some relatives (primarily inhabitants of grasslands and arid environments), break free from the ground when mature and bounce wherever the wind blows (Bates 2004). These fungal tumbleweeds are formally termed "geanemochorous tumblers" (Kreisel 1962) and are very effective at dispersal, but they occur almost exclusively in windy, open environments. Capped mushrooms and shelf mushrooms grow in a wider array of habitats and release millions of spores through a function called ballistospory that forcibly discharges spores from their reproductive surfaces (Money 1998). Theoretically, the discharged spores will then be widely disseminated by air currents. This mode of dispersal is ubiquitous among many groups of fungi, and yet the majority of spores land within one metre of the parent mushroom (Galante et al. 2011, Horton et al. 2013). These fruiting morphologies are not entirely dependent on mycophagous animals, but even animals with relatively small home ranges can significantly increase spore dispersal through their scats. Associations with animals provide selective pressure toward fungi that suit particular food/nutritional preferences or those that produce colours and/or aromas that can be detected by the organisms that will then disperse them (Fogel \& Trappe 1978, Maser et al. 1978, Claridge \& May 1994, Elliott \& Marshall 2016). Some of the underground sequestrate (truffle-like) fruiting morphologies often have strong olfactory cues (Maser et al. 1978), and this morphology has arisen independently in multiple fungal lineages (Elliott \& Trappe 2018). These fruiting morphologies may have convergently evolved due to the selective advantage of animal dispersal.

A wide diversity of vertebrates and invertebrates use fungi as major components in their diets (Carr 1952, Fogel \& Trappe 1978, Meurant 2012, Cooper \& Vernes 2011, Elliott et al. 2019b, Elliott \& Vernes 2019). Fungi are highly nutritious and contain significant levels of amino acids, protein and water (Vogt et al. 1981, Blair et al. 1984, Cork \& Kenagy 1989a, Hussain \& Al-Ruqaie 1999, Claridge \& Trappe 2005, Kalač 2009, Wallis et al. 2012, Bederska-Łojewska et al. 2017), making them nutritionally very important to many animals. Many groups of organisms have yet to be systematically studied to determine whether or not they consume fungi. In research on birds, the methods used do not typically account for fungi in the diet; thus, fungi have been a mostly overlooked dietary component for birds in the past (Elliott \& Vernes 2019, Elliott et al. 2019a). More than 250 species of mammals regularly eat fungi (Fogel \& Trappe 1978, Claridge \& May 1994, Nuske et al. 2017, Elliott unpublished data), but studies of these associations are heavily biased toward certain groups of mammals and overlook others entirely (Elliott et al. 2018). In this review, we aim to demonstrate the diversity of reptile species recorded to eat fungi and provide insight into the important ecological implications of this behaviour.

\section{Methods and limitations}

The methods we follow are used in an attempt to understand the ecological impacts of mutually beneficial associations between reptiles and macrofungi, particularly those involving 
diets. Because our focus is on the consumption and dispersal of macrofungi, our review excludes associations between reptiles and fungal pathogens and the chance ingestion of microfungi. We have considered extant reptiles; these include Archosauria (e.g. crocodiles, birds), Lepidosauria (e.g. tuatara, lizards, snakes and amphisbaenas) and Testudines (e.g. turtles) (Field et al. 2014, Benson 2018). We briefly discuss extinct reptiles (i.e. dinosaurs). We have excluded birds (Aves) because they are ecologically distinct and considered in detail elsewhere (Simpson 1998, 2000, Elliott \& Vernes 2019, Elliott \& Elliott 2019, Elliott et al. 2019a).

Many of the papers we reviewed did not identify the fungi (even at the generic level), so it was not possible to include a complete list of fungal species eaten by reptiles. We therefore focused on the diversity of reptiles that consume fungi. For practical reasons, we have restricted our literature searches to those written in English and Spanish. We have used a variety of relevant search terms and keywords, carefully examined cited reference lists within relevant papers and conducted methodical searches in relevant journals, databases and search engines for papers about the behaviours and diets of hundreds of reptile species. Depending on the known behaviours of some species, genera, families and orders, we put more or less effort into seeking out dietary studies; e.g., limited effort was given to reviewing sea turtle diets, but substantial effort was directed to that of various groups of terrestrial turtles. We do not infer reptile mycophagy from captive animal behaviour unless individuals were observed in large enclosures that allowed for virtually free movement and food choice, such as the example given for Centrochelys sulcata.

There has been little consistency in terms used by researchers to describe vertebrates eating fungi. The behaviour has been referred to as any of the following: mycophagy, mycophagous, fungivory, fungivore, endozoochorous, mushroom eating or fungus eating. Other authors use none of these terms and only mention a fungal taxon (or taxa) in the diet list. Terms describing the food item range from formal species names to general terms including toadstool, shelf-mushroom, bracket fungus, truffle and puffball. Diverse and non-standard terminology hinders the development of a coherent body of knowledge for these associations.

We strongly encourage authors who discuss reptiles eating fungi to use standardised terms. Our recommendations are "mycophagy" for the action of eating fungi, with "fungus" (or "fungi") used to describe the dietary item(s). We also strongly encourage researchers to collect, voucher (lodge with a recognised herbarium) and identify (as specifically as possible) the fungus involved in the association. Adoption of these practices would allow for a much more comprehensive understanding of the impacts of reptiles on fungal dispersal and the importance of different fungi in reptile nutrition. We hope this paper serves as a foundation for further research and improves understanding of these important associations between reptiles and fungi.

\section{Results}

\section{Mycophagy among reptiles}

Mycophagy is prevalent among reptiles (Tables 1, 2), but this is the first review to assess worldwide reptilian mycophagy and do so across broad taxonomic groups. Given how little is known about fungi in the fossil record, it is difficult to determine which would have been the earliest prehistoric reptiles to utilise fungi for food. Some dinosaurs in the late Cretaceous Period fed on wood that was heavily decomposed by white rot fungi, which possibly indicates that fungi and/or fungal rotted wood were components in dinosaur diets (Chin 2007, Chin et al. 2017). The mycorrhizal fungal genus Glomus has been found in coprolites of dinosaurs from the late Cretaceous (Kar et al. 2004), but given the small size of the fruiting bodies of this fungal genus, it is likely that they were incidentally consumed during feeding on other material. However, these findings do indicate that some dinosaurs may have served as dispersers of fungi. Other research has also shown fungal spores in dinosaur coprolites (Ghosh et al. 2003), but there is no available data indicating whether these spores represent contamination or deliberate feeding on fungal fruiting bodies. It is difficult to reconstruct the diets of long-extinct animals, so we can only hypothesize. Some species of Cretaceous reptiles likely ate fungi, and the selective advantage of this mode of 
dispersal may have altered some of the evolutionary trajectories of fungi to produce some of the current fungal fruiting morphologies. Regardless of what evolutionary pressures or advantages may or may not have been occurring between fungi and reptiles in prehistoric times, we do know that at least 42 extant reptile species eat fungi (Tables 1, 2).

Mycophagy has been erratically studied among different groups of reptiles. Most studies report fungi consumption from observations of wild or captive animals' feeding habits or occasionally from dissections of stomachs. This observational data is important, but it provides an incomplete picture. Studies of the diet of the turtle Indotestudo elongata note that fungi are the fourth largest dietary group and compose about 7\% of the diet (van Dijk 1998). But van Dijk (1998) also argued that this information is misleading because fungi are likely ingested far more frequently but often overlooked due to their digestibility. This study did not use methods that would have detected spores, so it could only account for fungal tissue that was not fully digested. The digestibility of fungi is a useful trait in vertebrate nutrition but is problematic to researchers evaluating reptile diets. For example, a study by Koenig et al. (2001) found that fungi were detectable in the diets of the blue-tongued lizard (Tiliqua scincoides) by dissecting stomachs but were not detectable in their scats. If the study had been restricted to scats, the fungal aspect of this animal's diet would have been completely overlooked. Similar issues are reported from observational studies of the turtle Kinixys belliana, which ate fungi that were not detectable through examinations of gastrointestinal or feacal samples (Kuchling 1986). These are only a few examples of the difficulty in assessing the importance of fungi as food, and they show why fungi have frequently been overlooked in reptile dietary studies. Jones et al. (2007) showed the viability of many different fungi cultured from the scats of $T$. carolina, but the fungi they reported belonged to groups whose fruiting bodies are too small to have been deliberately eaten by the turtles. However, this study provides additional evidence that fungal spores remain viable after passage through reptilian digestive systems.

Generally, all fungal tissues except spores break down relatively early in the digestive tract (some species more than others); unless the scats or stomach contents are examined at $400 \mathrm{X}$ magnification or higher, it is not feasible to reliably detect whether or not fungi were consumed by vertebrates (Elliott \& Vernes 2019). Many of the mammals that are widely recognised to rely heavily on fungi have never been observed consuming a fungus; this reiterates the importance of microscopic examination. It is likely that methodological oversights have led to a misrepresentation of which reptile species consume and disperse fungi. In addition to the species that directly ingest fungi, many reptiles (e.g., snakes) likely act as secondary dispersers by eating many organisms that eat fungi.

The remainder of the review is divided into three subsections: (1) Turtle Mycophagy, (2) Mycophagy Among Squamate Reptiles and (3) Secondary Dispersal of Fungi by Reptiles.

\section{Turtle mycophagy}

Fungi are an important food source for turtles in Africa, Asia, Europe, North America and South America (Table 1). The consumption of fungi by terrestrial turtles has been better studied than that of any other group of reptiles, making it possible to more thoroughly review and assess the impact of these associations on ecosystems around the world. Among all of the turtle species known to eat fungi, Terrapene carolina is the most commonly reported mycophagous species. We found 21 studies published between 1892 and 2018 reporting mycophagy by this species alone (Table 1). This is more than twice the number of reports for any other reptile. Creaser (1940) wrote of the fondness T. carolina has for fungi after watching an individual eating an Amanita vaginata mushroom: "The turtle had so gorged itself with the fleshy fungus that it was unable to close the plastron without emitting some.” On multiple occasions, the first author has observed this species feeding on fungi or found its distinctive bite marks left behind on fruiting bodies (Fig. 1). Terrapene carolina readily eats fungi, but the high number of reports more likely reflects the wide distribution of the species rather than any greater preference for fungi. The species is common throughout eastern North America, where its behaviour has been widely observed by many 
professional and amateur herpetologists. Many notes and reports on its diet have been published as a result. If the distribution of other terrestrial turtles coincided with equally high numbers of observant naturalists, we would likely have a far greater understanding of the importance of fungi to other turtle species. Unfortunately, this is not the case.

Even fungal taxa that are highly toxic to humans are important foods for some vertebrates (Fogel \& Trappe 1978). Among non-captive turtles, we have not found reliable reports of fungal poisonings. The most commonly referenced case of fungal turtle poisoning is Ballou (1927), which reports the following observation about $T$. carolina:

"One point I wish to make is that the squirrel seems to differentiate between the edible and the poisonous species, apparently never touching the latter. In this matter it is unlike the box tortoise which does not discriminate. In consequence, we find tortoise skeletons in the woods and fields, examination having shown that the animals had devoured the deadly Amanita phalloides. Most species of vertebrates, including frogs, snakes, lizards, and domestic stock, eat mushrooms.”

This 1927 report is problematic for several reasons. One major issue is that A. phalloides is a European fungus that was not confirmed in North America (in California) until 1938 (Pringle et al. 2009). This western North American report is well outside the range of T. carolina, and Amanita phalloides was not confirmed within the range of T. carolina until the 1970's (Wolfe et al. 2010). There are also many reports that contradict Ballou by showing that squirrels and other animals regularly eat fungi that are considered toxic to humans (Fogel \& Trappe 1978). Ballou does not rule out any other probable causes of death, so fungal poisoning is merely an assumption. As stated earlier, T. carolina also happens to be the most documented mycophagous reptile species in the world (Table 1).

There is evidence that turtles (particularly T. carolina) that eat toxic fungi may be able to utilise the toxins to their advantage to ward off predators. It is not known how these toxins affect wildlife, but according to traditional knowledge among turtle hunters in North America, there are reports of poisoning from turtles that had been feeding heavily on fungi. During a 1902 coal mine strike in Scranton, Pennsylvania, food shortages led some miners to eat T. carolina; some reportedly fell ill due to toxins from poisonous fungi eaten by the turtles (Surface 1908). Other herpetologists have provided similar accounts. Smith (1956) wrote the following warning about the dangers of eating $T$. carolina: "The flesh is palatable, but a person who dines upon these turtles does so with some risk because the poison of the mushrooms eaten by them which does not deleteriously affect the turtles is reported to be transferred undiminished in potency to man who unfortunately is not immune to its effect." Carr (1952) suggested that turtles may deliberately eat toxic mushrooms: “...it is said that poisonous ones [mushrooms] are eaten with impunity and that this may account for the fact that people are sometimes poisoned by eating box turtles." Carr (1952) also writes specifically about the subspecies T. carolina triunguis as being poisonous to humans and reports an account of boys in Mississippi accidentally cooking several while burning brush and subsequently eating them. They allegedly fell ill after consumption.

From the standpoint of turtle conservation, it is fortunate that there are far fewer $T$. carolina turtles being eaten by humans in North America than when these aforementioned authors were writing; however, this likely means that the chemical source of historic turtle poisoning will remain a mystery. There are many species of terrestrial turtles still being eaten by humans in Asia and other parts of the world, and some of these turtle species regularly consume fungi (Table 1). We were unable to find evidence of poisonings attributed to turtle meat outside of North America. Further research is needed to determine if the link between T. carolina poisonings and fungi is a myth, if other turtles are eating different groups of less toxic fungi or if there is a specific cooking process that can detoxify the meat.Regardless of whether or not fungi provide some turtles with chemical defenses against predators, fungi are important to the overall health and nutrition of turtles. There is evidence shown in captive rearing programs that fungi benefit turtle health and growth if they are included as a major or exclusive component in the diet; the standard protocol for raising healthy 
captive populations of the critically endangered Pyxis planicauda is a diet composed of $40 \%$ fungi (Bonin et al. 2006). Some of the difficult-to-raise turtle species such as Manouria impressa have been kept alive and healthy on diets that are heavily or exclusively composed of fungi (Espenshade \& Buskirk 1994, Sitha et al. 2006, Brock 2009).

Table 1 List of 32 species of turtles documented to eat fungi. This list relies on the taxonomic abilities of the cited authors. Names applied in the left two columns are based on the current standardised classification of reptiles in: http://images.turtleconservancy.org/documents/2017/crm-7-checklistatlas-v8-2017.pdf. Current names used in this table may have changed since the original reference. The region column has the abbreviation of the continent where the species has been found. This does not include regions where species may have been introduced or become naturalized. (AF = Africa, AS = Asia, AU = Australia, EU = Europe, NA = North America, SA = South America)

\begin{tabular}{|c|c|c|c|c|}
\hline Turtle Family & Common Name(s) & Latin Name & Region & Report Citation \\
\hline Chelidae & Northern Snapping Turtle & Elseya dentata & AU & Kennett \& Tory 1996 \\
\hline Pelomedusidae & $\begin{array}{l}\text { African Helmeted Turtles, } \\
\text { African Helmeted Terrapins }\end{array}$ & Pelomedusa subrufa & $\mathrm{AF}$ & Luiselli et al. 2011 \\
\hline \multirow[t]{4}{*}{ Emydinae } & Wood Turtle & Glyptemys insculpta & NA & $\begin{array}{l}\text { Wright 1892, Surface 1908, Strang 1983, Walde et al. 2003, } \\
\text { Sweeten 2008, Jones \& Sievert } 2009\end{array}$ \\
\hline & $\begin{array}{l}\text { Eastern Box Turtle, Common } \\
\text { Box Turtle }\end{array}$ & Terrapene carolina & NA & $\begin{array}{l}\text { Wright 1892, Webster 1902, Surface 1908, Latham 1916, Nichols } \\
\text { 1917, Conant 1938, Creaser 1940, Allard 1948, Stickel 1950, Carr } \\
\text { 1952, Smith 1956, Smith 1961, Dolbeer 1969, Strang 1983, } \\
\text { Jordan 2004, Liu et al. 2004, Bonin et al. 2006, Jones et al. 2007, } \\
\text { Weiss 2009, Fleckenstein et al. 2015, Elliott \& Stephenson } 2018\end{array}$ \\
\hline & Coahuilan Box Turtle & Terrapene coahuila & NA & Brown 1974 \\
\hline & $\begin{array}{l}\text { Ornate Box Turtle, Western } \\
\text { Box Turtle }\end{array}$ & Terrapene ornata & NA & $\begin{array}{l}\text { Rose 1988, Bonin et al. 2006, Morrow 2008, Worthington et al. } \\
2017\end{array}$ \\
\hline \multirow[t]{6}{*}{ Geoemydidae } & Bourret's Box Turtle & Cuora bourreti & AS & Espenshade \& Duc 2000, Xiao et al. 2017 \\
\hline & Keeled Box Turtle & Cuora mouhotii & AS & Ji-Chao et al. 2011, Xiao et al. 2017 \\
\hline & Asian Leaf Turtle & Cyclemys dentata & AS & van Dijk 1998 \\
\hline & Black-breasted Leaf Turtle & Geoemyda spengleri & AS & Espenshade \& Duc 2000 \\
\hline & Cochin Forest Cane Turtle & Vijayachelys silvatica & AS & Lenin 2006, Whitaker \& Vijaya 2009 \\
\hline & Spiny Turtle & Heosemys spinosa & AS & Goetz 2007 \\
\hline \multirow[t]{5}{*}{ Testudinidae } & African Spurred Tortoise & Centrochelys sulcata & $\mathrm{AF}$ & This study \\
\hline & Red-footed Tortoise & Chelonoidis carbonaria & SA & Moskovits \& Bjorndal 1990, Wang et al. 2011 \\
\hline & Yellow-footed Tortoise & Chelonoidis denticulata & SA & $\begin{array}{l}\text { Bayona \& Rylander 1984, Moskovits \& Bjorndal 1990, Guzmán } \\
\text { \& Stevenson 2008, Jerozolimski et al. 2009, Lodge et al. } 2016\end{array}$ \\
\hline & $\begin{array}{l}\text { Angulate Tortoise, South } \\
\text { African Bowsprit Tortoise }\end{array}$ & Chersina angulata & $\mathrm{AF}$ & Joshua 2008 \\
\hline & Mojave Desert Tortoise, & Gopherus agassizii & NA & Hansen et al. 1976 \\
\hline
\end{tabular}


Table 1 Continued.

\begin{tabular}{|c|c|c|c|c|}
\hline \multirow{17}{*}{ Turtle Family } & Common Name(s) & Latin Name & Region & Report Citation \\
\hline & $\begin{array}{l}\text { Mohave Desert Tortoise, } \\
\text { Agassiz's Desert Tortoise }\end{array}$ & & & \\
\hline & Gopher Tortoise & Gopherus polyphemus & NA & Brode 1959, MacDonald \& Mushinsky 1988 \\
\hline & $\begin{array}{l}\text { Elongated Tortoise, Yellow- } \\
\text { headed Tortoise }\end{array}$ & Indotestudo elongata & AS & $\begin{array}{l}\text { van Dijk 1998, Platt et al. 2001, Bonin et al. 2006, Platt et al. } \\
\text { 2007, Ahmed \& Das 2010, Ihlow et al. 2012, Sriprateep et al. } \\
\text { 2013, Das \& Gupta } 2015\end{array}$ \\
\hline & $\begin{array}{l}\text { Forsten's Tortoise, Sulawesi } \\
\text { Tortoise }\end{array}$ & Indotestudo forstenii & AS & Moll 1989 \\
\hline & Travancore Tortoise & Indotestudo travancorica & AS & $\begin{array}{l}\text { Vijaya 1983, Bonin et al. 2006, Vasudevan et al. 2010, Deepak } \\
\text { 2011, Veerappan \& Vasudevan 2012, Deepak } 2015\end{array}$ \\
\hline & Bell's Hinge-back Tortoise & Kinixys belliana & $\mathrm{AF}$ & $\begin{array}{l}\text { Loveridge \& Williams 1957, Bertram 1979, Kuchling 1986, } \\
\text { Broadley 1989b, Luiselli 2003, Glaw \& Vences } 2007\end{array}$ \\
\hline & $\begin{array}{l}\text { Forest Hinge-back Tortoise, } \\
\text { Serrated Hinge-back Tortoise }\end{array}$ & Kinixys erosa & $\mathrm{AF}$ & Luiselli 2003, 2006, Mifsud \& Stapleton 2014 \\
\hline & Home's Hinge-back Tortoise & Kinixys homeana & $\mathrm{AF}$ & Luiselli 2003, 2006 \\
\hline & Lobatse Hinge-back Tortoise & Kinixys lobatsiana & $\mathrm{AF}$ & Power 1926, Bonin et al. 2006 \\
\hline & Speke's Hinge-back Tortoise & Kinixys spekii & $\mathrm{AF}$ & $\begin{array}{l}\text { Loveridge 1923, Broadley 1989c, Hailey \& Coulson 1996, Hailey } \\
\text { et al. 1997, Hailey et al. 2001, Mifsud \& Stapleton } 2014\end{array}$ \\
\hline & $\begin{array}{l}\text { Southeastern Hinge-back } \\
\text { Tortoise }\end{array}$ & Kinixys zombensis & $\mathrm{AF}$ & Mifsud \& Stapleton 2014 \\
\hline & Asian Giant Tortoise & Manouria emys & AS & Heiss et al. 2011 \\
\hline & Impressed Tortoise & Manouria impressa & AS & $\begin{array}{l}\text { Chan-ard et al. 1996, Espenshade \& Duc 2000, Sitha et al. 2006, } \\
\text { Wanchai 2012, Wanchai et al. 2012, } 2013\end{array}$ \\
\hline & $\begin{array}{l}\text { Flat-tailed Tortoise, Flat- } \\
\text { shelled Spider Tortoise }\end{array}$ & Pyxis planicauda & $\mathrm{AF}$ & Gibson \& Buley 2004, Pedrono \& Smith 2013 \\
\hline & Leopard Tortoise & Stigmochelys pardalis & $\mathrm{AF}$ & Broadley 1989a, Bonin et al. 2006 \\
\hline & Hermann's Tortoise & Testudo hermanni & EU & $\begin{array}{l}\text { Meek 2010, Rozylowicz \& Dobre 2010, Bertolero et al. 2011, Del } \\
\text { Vecchio et al. 2011, Mafli et al. } 2011\end{array}$ \\
\hline
\end{tabular}

Some turtles retain/store water in their bodies for dry times to re-absorb as needed; since some fungi are composed of up to $90 \%$ water, they can serve as a vital source of hydration (Peterson 1996, Wanchai 2012). Six species of the African turtle genus Kinixys regularly eat fungi (Table 1), and their greatest growth rates occur during periods when fungi have made up the largest portions of their diets (Mifsud \& Stapleton 2014). In K. spekii diets, millipede protein was more digestible than protein in fungi or leaves, but the intake rate of total and digestible protein was higher in fungi than the other two food items (Hailey et al. 1998). Similar benefits apply to Manouria impressa, which generally prefers fungal foods and tends to be most 
active at the peak of fungal fruiting season (Chan-ard et al. 1996, Wanchai et al. 2013); fungi may impact the turtle's behaviour by influencing the times when it is most active. There is indication in Chelonoidis carbonaria that only males eat fungi, possibly because they require different amounts or types of protein than females do (Wang et al. 2011). We have found no other studies indicating significant differences in fungal preference between the sexes, though most studies did not take this into account.

Our review shows that fungi are a food source for 32 turtle species, but the larger ecological impact of turtle spore dispersal depends on the taxa of fungi eaten. In order to evaluate this aspect of turtle mycophagy, future research must focus more attention on identifying the species of fungi being eaten. Among the turtle species that have been reported to eat fungi, only a handful have been studied sufficiently enough for us to evaluate the larger ecosystem implications of mycophagist associations. Turtles eat both mycorrhizal and saprotrophic fungi and are therefore dispersing two ecologically very different groups through their scats. Manouria impressa eats disproportionately more ectomycorrhizal species than non-mycorrhizal species (Chan-ard et al. 1996, Wanchai 2012), which likely indicates its role as an important dispersal agent in Southeast Asian ectomycorrhizal forests. In Africa, the turtle genus Kinixys and particularly $K$. spekii has been widely reported to be mycophagous (Table 1). Interestingly, K. spekii eats a lot of fungi in woodlands dominated by trees in the genera Brachystegia and Julbernardia (Hailey et al. 1997). These two tree genera are both ectomycorrhizal (Högberg \& Piearce 1986) and are likely the symbionts of many of the fungi that are important foods to the turtle. Kinixys spekii also eats the fruits of the ectomycorrhizal tree Uapaca kirkiana (Lambiris et al. 1989, Mwamba 1995); since seeds of this tree and associated symbiotic fungi likely simultaneously end up in the stomach and then scats of $K$. spekii, the tree would benefit from having both fertilizer and fungal inoculant deposited with its seeds.

Turtles are effective dispersers of plants, and seed germination rates increase in some cases after passage through the stomachs of these animals (Rust \& Roth 1981, Braun \& Brooks 1987, Cobo \& Andreu 1988, Moll \& Jansen 1995, Varela \& Bucher 2002, Jordan 2004, Liu et al. 2004, Jerozolimski et al. 2009; Valencia-Aguilar et al. 2013). Assessing retention time of seeds or spores is important for the estimation and/or modeling of dispersal potential. This can be a difficult and very variable aspect of vertebrate physiology; retention time inevitably varies between individuals and species, the digestibility of the food items, the temperature/season when foods were consumed and whether or not the study was conducted on captive or wild individuals. Seeds ingested by Chelonoidis denticulata were on average dispersed 174.1 metres from where they were ingested (Jerozolimski et al. 2009). Dye added to turtles' food has passed through the digestive tract in 24-48 hours (Moll \& Jansen 1995), yet the maximum retention time for seeds can be as long as 14-20 days (Braun \& Brooks 1987, Cobo \& Andreu 1988, Varela \& Bucher 2002). In captive feeding trials, Hailey (1998) found that it could take four days for fungi to pass through the digestive tract of K. spekii; however, this was not based on spore analysis of faecal samples, and spores are likely retained even longer. Turtles' retention times are highly variable and have yet to be assessed through microscopic examination of spores. Based on studies addressing this question in mammals, fungal spores can linger in digestive tracts after the bulk of the meal has already passed through. In mammals, maximum retention times of fungal spores are also highly variable and depend on many factors (e.g. the size of the individual, the morphology of the digestive tract, other dietary components simultaneously eaten and the current health of the individual). These rates have only been specifically studied in relation to fungal spores among four mammal species, and these maximum figures range from 69 to 120 hours after ingestion (Cork \& Kenagy 1989b, Comport \& Hume 1998, Danks 2012). How similar these maximum retention times are in reptiles has yet to be determined, but a study by Hailey (1998) showing a retention time of four or possibly more days indicates that some turtles likely retain fungal tissue for similar if not longer periods than mammals do. Retention time of at least four days allows for significant movement, even for relatively slowmoving turtles. Terrapene carolina regularly eats fungi (Table 1 \& Fig. 1) and travels as far as 139 metres in a day, but this is usually within a relatively small home range (Stickel 1950). Seeds are 
retained in the digestive systems of this species for up to 20 days (Braun \& Brooks 1987), and spores would likely be retained for similar periods of time. These long retention rates likely indicate improved spore dispersal for fungi if ingested by turtles, which translates into improved associations within plant communities and positive impacts on overall forest and ecosystem health.
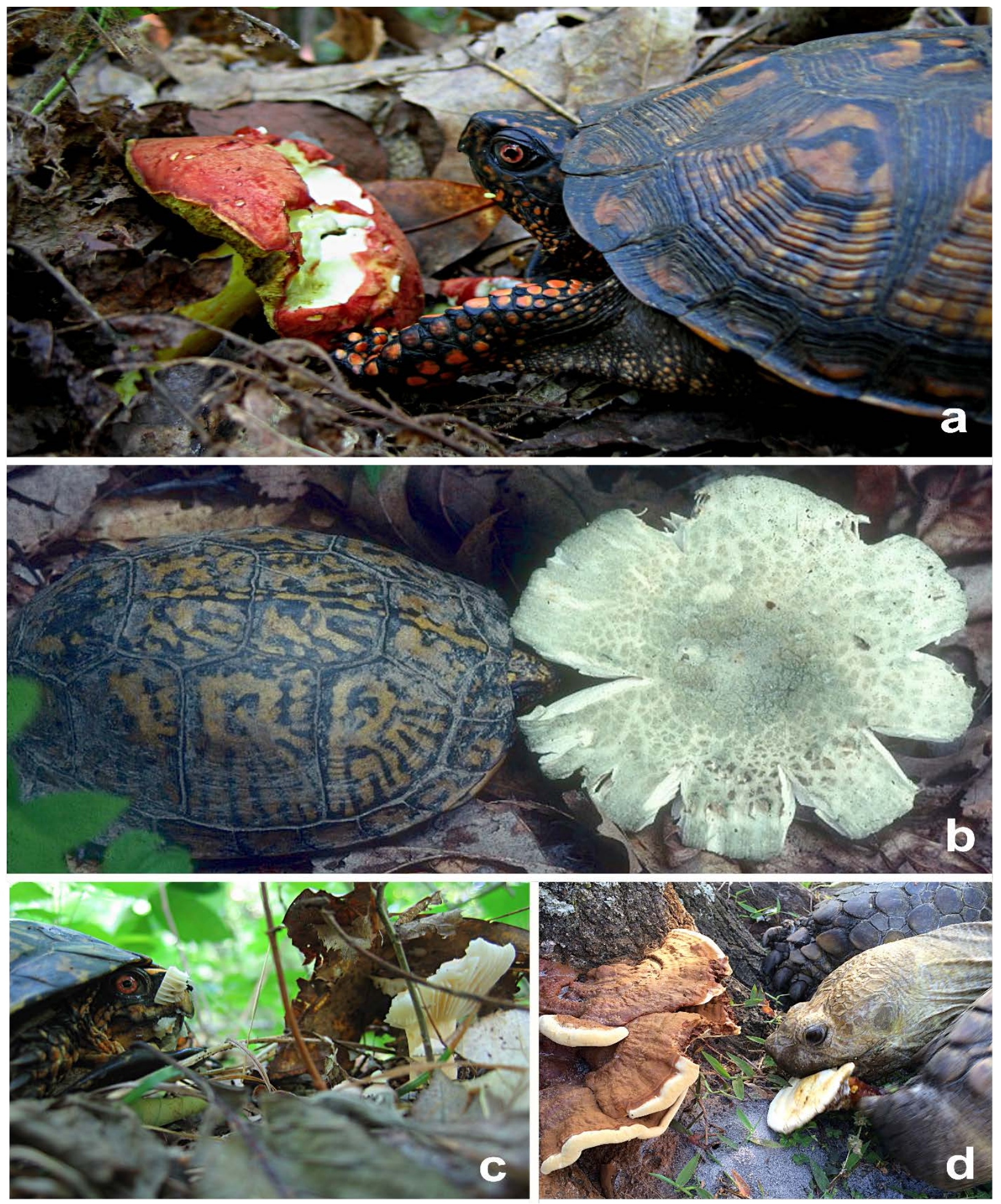

Figure 1 - Photos illustrating turtles' fondness for fungi as food. a A male Terrapene carolina eating a species of bolete in Rutherford County, North Carolina, USA. Photo (c) Todd F. Elliott. b Russula parvovirescens being eaten by T. carolina in Beaver Creek State Forest, Ohio, USA. Photo (C) Walt Sturgeon. c Lactarius volemus being consumed by T. carolina in Rutherford County, North Carolina, USA. Photo (C) Todd F. Elliott. d A free ranging male Centrochelys sulcata feeding on a Ganoderma sp. in Stuart, Florida, USA. Photo (C) Amanda Hipps. 
In the course of writing this review, we received a report from herpetologist Amanda Hipps of Florida Atlantic University stating that her approximately 27-year-old male Centrochelys sulcata regularly seeks fungi to eat when allowed to wander freely in her yard in Stuart, Florida (Fig. 1). Although this is a report of a single individual outside of its native habitat, it is noteworthy since this genus of turtles has not been previously reported to eat fungi. From photos and video clips provided by Hipps, we were able to determine that this individual has eaten at least two different species of fungi. One fungus eaten by this C. sulcata individual is a species of Ganoderma. It is likely either G. curtisii or G. sessile, but it is not possible to definitively determine the species from the photo (Fig. 1). The other fungus eaten appears to be a species of Lentinus.

\section{Mycophagy among squamate reptiles}

There are far fewer reports of mycophagy among the squamate reptiles than among turtles. We found reports of 10 species of skinks and teiid lizards that ate fungi. Both groups consume a diversity of macrofungi, including decomposers and mycorrhizal species (Wolcott 1924, Cooper \& Vernes 2011). These associations have been more thoroughly documented among skinks than other squamate taxa. The lack of mycophagy reports for lizards versus turtles may be partly due to a difference in dietary preferences, but we also suspect a positive bias toward turtles because they tend to be slower-moving and easier to observe. The larger-bodied species of Australian skinks have most frequently been documented to eat fungi, and they also happen to be some of the less shy and more easily observed species. We have not found any reports of stomach analysis for these groups of reptiles using methods that would detect spores of fungi in the scats or stomachs. The infrequent mention of fungi in the literature, particularly among the larger-bodied species, is likely due to stomach and scat samples not being examined at 400X magnification or higher.

Lizards with body weights greater than 300 grams tend to be herbivorous (Pough 1973). This is likely due to the biomass of food needed to sustain such relatively large body weights. Many of these larger species are carnivorous as juveniles until they reach 50-300 grams, at which point they become more herbivorous (Pough 1973). Fungal fruiting bodies contain more biomass of protein and nutrients than many plant materials (Wallis et al. 2012), which potentially makes them far more important in lizard diets than has been previously recognised.

There are a few reports of lizard poisonings due to fungal ingestion. The reports we are aware of involve individuals raised in captivity whose behaviour is inevitably different than their wild relatives; furthermore, specificity of the taxonomy of fungi ingested in these reports is generally lacking. For example, Fitzgerald \& Newquist (2008) report that a "pet iguana ingested Amanita pantherina" and fell ill; they then go on to describe the fungus as having a "brilliant red cap," which is not the colouration of A. pantherina but likely in reference to a member of the A. muscaria complex (Takashi et al. 2004). However, as no photo or voucher specimen was provided, we are unable to confirm which fungus was actually consumed. We have found no evidence that fungal poisonings have actually occurred among wild individuals; and given the nutritive value of fungi, there is strong evidence that they are important dietary components.

The current data on lizard mycophagy is not sufficient enough to provide much insight into the larger ecological implications of these associations. We do know that 10 species eat fungi and are contributing to their dispersal, and most of these species are found in Australia (Table 2). The ectomycorrhizal groups Setchelliogaster, Zelleromyces and an "unidentified bolete" have all been found in the diet of the southern blotched blue-tongue lizard (Tiliqua nigrolutea) (Webb \& Simpson 1985). The genus Zelleromyces is usually hypogeous, indicating that skinks may use sense of smell to detect fungal fruiting bodies. Further support that skinks might be able to detect aromas produced by hypogeous fungi is provided by Schulz \& Eyre (1997), who noted that the land mullet skink (Egernia major) digs up and eats fungi. On 23 November 2018, the first author observed a large Tiliqua scincoides eating the mature fruiting bodies of the stinkhorn fungus Aseroe rubra in Armidale, New South Wales (Fig. 2). The skink forced several specimens out of the leaf litter with its face and gradually ate the entire fruiting body (including reproductive tissues). It seemed 
possible that the skink detected the location of the fruiting bodies by smell, but further experimental study needs to be conducted to confirm this hypothesis. This lizard species and many others have complex olfactory and vomeronasal organs that allow them to pick up a diversity of smells (Kratzing 1975, Vitt \& Cooper 1986, Cooper \& Vitt 1989) and possibly make them particularly adept at detecting fungal odours. This is not the first report of the pungent smelling fungus A. rubra being eaten by this species; Cooper \& Vernes (2011) report the same phenomenon in the same region of Australia. We hope that this review will trigger modifications in scat and stomach analysis methods to allow for further research into the associations between these organisms. These associations likely play a larger role in both fungal dispersal and squamate reptile nutrition than has previously been shown.

Table 2 List of 10 species of lizards and skinks documented to eat fungi. This list relies on the taxonomic abilities of the cited authors. Names applied in the left two columns are based on the current standardized classification of reptiles in: http://reptile-database.reptarium.cz/ and may not be the same as at the time of the original publication. We made every effort to only include reports of macro-fungi in this table. The region column has the abbreviation of the continent where the species has been found. This does not include regions where species may have been introduced or become naturalized. $(\mathrm{AU}=$ Australia, NA = North America, SA = South America)

\begin{tabular}{|c|c|c|c|c|}
\hline Family & Common Name(s) & Latin Names & Region & Report citation \\
\hline \multirow[t]{2}{*}{ Teiidae } & $\begin{array}{l}\text { Common Puerto Rican } \\
\text { Ameiva }\end{array}$ & Pholidoscelis exsul & NA & Wolcott 1924 \\
\hline & Argentine Giant Tegu & Salvator merianae & SA & Toledo et al. 2004 \\
\hline \multirow[t]{8}{*}{ Scincidae } & Land Mullet & Bellatorias major & AU & Schulz \& Eyre 1997, Shea 1999 \\
\hline & Black Crevice-skink & Egernia saxatilis & $\mathrm{AU}$ & Brown 1991 \\
\hline & Giant Bluetongue Skink & Tiliqua gigas & AU & Günther 1867, Gregory \& Lucas 1886 \\
\hline & $\begin{array}{l}\text { Centralian Blue-Tongued } \\
\text { Lizard }\end{array}$ & Tiliqua multifasciata & $\mathrm{AU}$ & Shea 2006 \\
\hline & $\begin{array}{l}\text { Southern Bluetongue, } \\
\text { Blotched Blue-Tongued } \\
\text { Lizard }\end{array}$ & Tiliqua nigrolutea & $\mathrm{AU}$ & Lucas \& Frost 1893, Lucas \& le Souef 1909, Webb \& Simpson 1985 \\
\hline & $\begin{array}{l}\text { Western Bluetongue, } \\
\text { Western Blue-Tongued } \\
\text { Lizard }\end{array}$ & Tiliqua occipitalis & $\mathrm{AU}$ & Dell \& Chapman 1979, Shea 2006 \\
\hline & $\begin{array}{l}\text { Shingleback Lizard, } \\
\text { Shingle-Back }\end{array}$ & Tiliqua rugosa & $\mathrm{AU}$ & $\begin{array}{l}\text { Anonymous 1892, Lucas \& Frost 1893, Waite 1925, Kershaw 1927, } \\
\text { Brazenor 1936, Longley 1944, Hyett 1961, Serventy 1970, Shea 1989, } \\
\text { Brown } 1991\end{array}$ \\
\hline & $\begin{array}{l}\text { Common Bluetongue, } \\
\text { Eastern Bluetongue }\end{array}$ & Tiliqua scincoides & AU & Koenig et al. 2001, Cooper \& Vernes 2011, Elliott this study \\
\hline
\end{tabular}



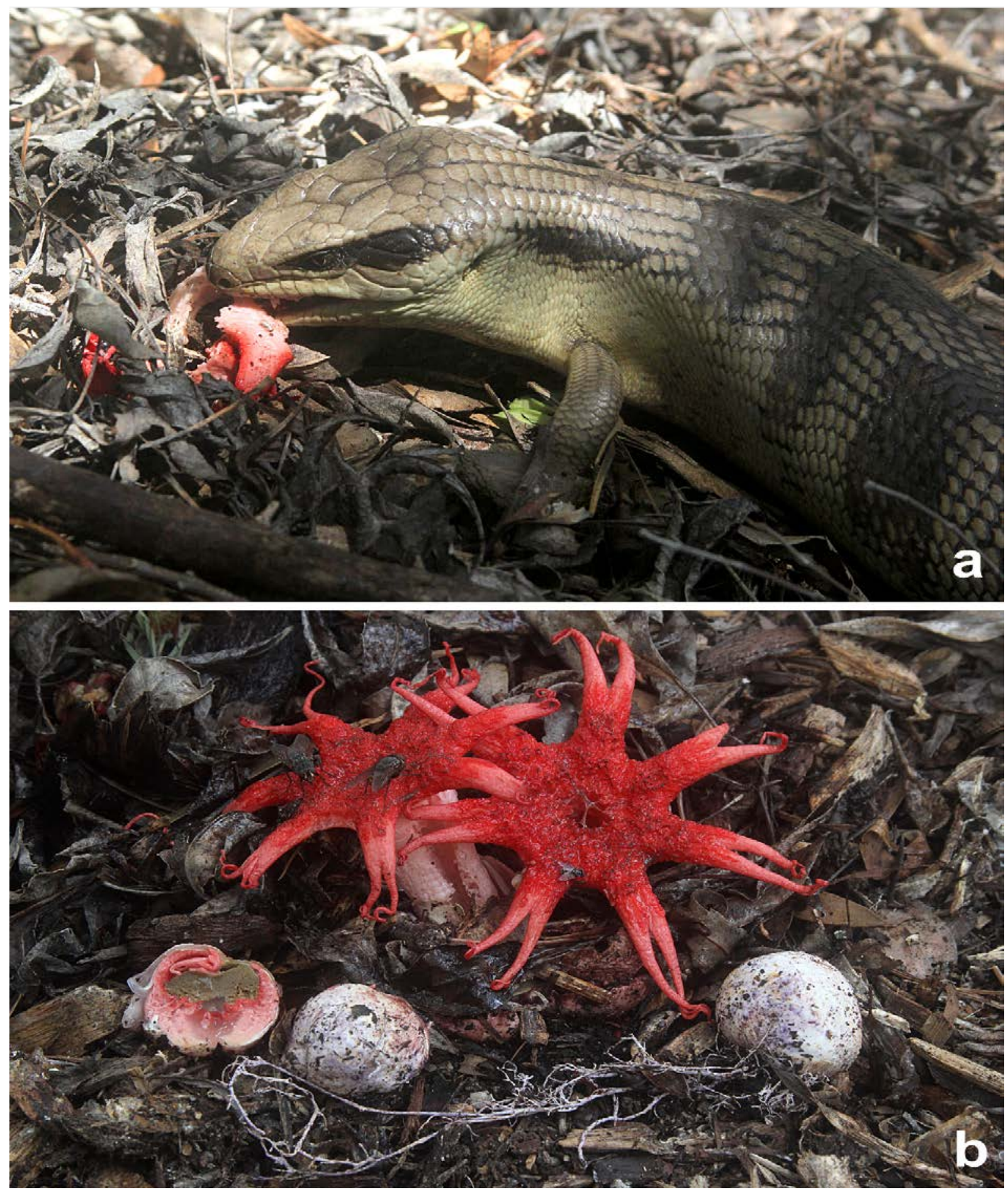

Figure 2 - The Australian skink species Tiliqua scincoides eating fruiting bodies of the fungus Aseroe rubra in Armidale, NSW, Australia. a Tiliqua scincoides eating a fruiting body that it has just excavated from the soil. b Mature fruiting bodies erupting from the soil and "eggs" (immature fruiting bodies) that were excavated by the first author. The immature fruiting body on the left side of the image has been sectioned to show the interior before maturation; also note the long rhizomorphs attached to the base of the excavated fruiting bodies. Note the two different species of flies (Diptera) visiting the mature fruiting bodies and likely playing a role in their dispersal along with the skink. All photos (C) Todd F. Elliott.

\section{Secondary dispersal of fungi by reptiles}

Secondary dispersal of fungi is undoubtedly occurring among reptiles, but we can find no previous discussion of this phenomenon in the literature. Toads act as secondary dispersers of 
viable fungal spores when they eat slugs that have eaten fungi (Vogilino 1895, Buller 1909). Many invertebrates eat significant amounts of fungi (Meurant 2012), and many lizards and turtles eat the same groups of insects that are known to eat fungi (Wolcott 1924, Chessman 1984, Lunney et al. 1989). Turtles frequently scavenge animal carcasses and eat the scats of other animals, including carnivores (van Dijk 1998). This scavenging behaviour inevitably leads to at least some secondary dispersal of fungal spores from the scats or stomach contents of other animals.

Snakes may be one of the most effective reptiles at dispersing fungal spores through secondary consumption. Hundreds, if not thousands, of snake species around the world eat mammals; for some groups of snakes, small mammals can compose an almost exclusive component of their diet (Fitch 1963, Gregory et al. 1980, Shine \& Covacevich 1983, Slip \& Shine 1988, Murphy \& Henderson 1997). Both constrictors and venomous snakes swallow their prey whole, and many of the mammal species regularly eaten by snakes-particularly rodents and small marsupials-eat a great diversity of fungi (Fogel \& Trappe 1978, Claridge \& May 1994, Nuske et al. 2017). Consequently, snakes likely serve as secondary dispersers of the fungi ingested by these small mammals. In some cases, snakes may disperse fungal spores farther than a small rodent would. There is a desperate need for studies testing the hypothesis of secondary dispersal of fungi by reptiles, and we hope this review will encourage more investigation into this aspect of ecology.

\section{Conclusions}

There are many regions around the world where a diversity of reptiles coexist with a diversity of fungi. In these ecosystems, there is a great need for further study of the interactions between these different yet interconnected groups of organisms. Madagascar is one such region; it has an incredible diversity of terrestrial tortoises, some of which are endemic to the island (Glaw \& Vences 2007). The diets of many of these species have been poorly studied in the wild, but many of their movement patterns peak during wet times (Glaw \& Vences 2007) when fungi are also at their peak of fruiting. This may indicate that fungi play an important role in their diets, just as they do in the diets of other terrestrial turtles. The Malagasy turtle (Pyxis planicauda) prefers fungi over other food sources in captivity, but there is very little known about its diet in the wild (Pedrono \& Smith 2003). We hypothesize that with further study and the application of microscopic analysis of faecal samples, it will become evident not only in Madagascar but also in many other regions around the world that terrestrial turtles and lizards are playing an important role as primary dispersers of fungi; furthermore, many of the carnivorous and insectivorous reptiles are likely key secondary dispersers. Further study is needed to fully assess these associations, but we hope that this review will lay the groundwork for a better understanding of these ecologically important interactions.

\section{Acknowledgements}

The research librarians at the Dixson Library of the University of New England in Australia were instrumental in enabling our access to some of the more obscure references cited in this manuscript. We are grateful to Amanda Hipps of Florida Atlantic University for providing an account and photo of the Centrochelys sulcata feeding on a Ganoderma (Fig. 1d). Walt Sturgeon graciously provided an image of Terrapene carolina feeding on Russula parvovirescens (Fig. 1c). Kelsey Myers Elliott provided helpful insights and editorial comments on the manuscript. The School of Environmental and Rural Science at the University of New England provided facilities and an International Postgraduate Research Scholarship to the first author. The Marshall family of Terra Preta Truffles and the Stricklands of Walnut Creek Preserve were instrumental in providing support for this project.

\section{References}

Ahmed MF, Das A. 2010 - Tortoises and Turtles of Northeast India: Saving them from Extinction!. (Draft) Technical Report, Aaranyak, HRCP: 01/2010. 86 pp. 
Allard HA. 1948 - The eastern box turtle and its behavior. Journal of the Tennessee Academy of Science 23, 307-321.

Anonymous Author. 1892 - Field Naturalist Club's Excursion to the Grampians. 21st November to 5th December, 1891. Victorian Naturalist 8, 181-196.

Ballou WH. 1927 - Squirrels as mushroom eaters. Journal of Mammalogy 8, 57-58.

Baer B, Den Boer SPA, Kronauer DJC, Nash DR, Boomsma JJ. 2009 - Fungus gardens of the leafcutter ant Atta colombica function as egg nurseries for the snake Leptodeira annulata. Insectes sociaux 56, 289-291.

Bates ST. 2004 - Arizona members of the Geastraceae and Lycoperdaceae (Basidiomycota, Fungi). (Doctoral dissertation, Arizona State University).

Bayona LOR, Rylander MK. 1984 - Notes on the Biology of the Tortoise Geochelone denticulate L. in Peru. Amphibia-reptilia 5, 323-327.

Bederska-Łojewska D, Świątkiewicz S, Muszyńska B. 2017 - The use of Basidiomycota mushrooms in poultry nutrition-A review. Animal Feed Science and Technology 230, 5969.

Benson RB. 2018 - Dinosaur Macroevolution and Macroecology. Annual Review of Ecology, Evolution, and Systematics 49, 379-408.

Bertolero A, Cheylan M, Hailey A, Livoreil B, Willemsen RE. 2011 - Testudo hermanni (Gmelin 1789) - Hermann’s Tortoise. Chelonian Research Monographs 5, 059.1-059.20.

Bertram BC. 1979 - Home range of a hingeback tortoise in the Serengeti. African Journal of Ecology 17, 241-244.

Blair RM, Alcaniz R, Morris Jr HF. 1984 - Yield, nutrient composition, and ruminant digestibility of fleshy fungi in southern forests. The Journal of Wildlife Management, 48(4), 1344-1352.

Bonin F, Devaux B, Dupré A. 2006 - Turtles of the World. John Hopkins University Press. London, $416 \mathrm{pg}$.

Braun J, Brooks Jr GR. 1987 - Box turtles (Terrapene carolina) as potential agents for seed dispersal. American Midland Naturalist 117, 312-318.

Brazenor CW. 1936 - The reptiles and amphibians of Victoria. The Victorian Year-Book. 1934-35, 25-38.

Brock J. 2009 - Keeping and breeding impressed tortoises (Manouria impressa). IRCF Reptiles \& Amphibians 16, 99-101.

Broadley DG. 1989a - Geochelone pardalis Leopard Tortoise (English) Bergskilpad (Afrikaans). In: Swingland IR, Klemens MK (Eds.): The Conservation Biology of Tortoises. Occas. Pap. IUCN Species Survival Commission, No. 5. IUCN Publ., Gland, Switzerland: 43-46.

Broadley DG. 1989b - Kinixys belliana, Bell's Hinged Tortoise. In: Swingland IR, Klemens MK (Eds.): The Conservation Biology of Tortoises. Occas. Pap. IUCN Species Survival Commission, No. 5. IUCN Publ., Gland, Switzerland: 49-52.

Broadley DG. 1989c - Kinixys spekii Speke's Hinged Tortoise. In: Swingland IR, Klemens MK (Eds.): The Conservation Biology of Tortoises. Occas. Pap. IUCN Species Survival Commission, No. 5. IUCN Publ., Gland, Switzerland: 52-54.

Brode WE. 1959 - Notes on behavior of Gopherus polyphemus. Herpetologica 15, 101-102.

Brown GW. 1991 - Ecological feeding analysis of south-eastern Australian scincids (Reptilia, Lacertilia). Australian Journal of Zoology 39, 9-29.

Brown WS. 1974 - Ecology of the aquatic box turtle, Terrapene coahuila (Chelonia, Emydidae) in northern Mexico. Bulletin Florida State Museum 19, 1-67.

Bruner G, Fernández-Marín H, Touchon JC, Wcislo WT. 2012 - Eggs of the blind snake, Liotyphlops albirostris, are incubated in a nest of the lower fungus-growing ant, Apterostigma cf. goniodes. Psyche: A Journal of Entomology 2012: 1-5.

Buller AHR. 1909 - Researches on Fungi I. Longmans, Green and Company. London. 287 pg.

Caldwell IR, Vernes K, Barlocher F. 2005 - The northern flying squirrel (Glaucomys sabrinus) as a vector for inoculation of red spruce (Picea rubens) seedlings with ectomycorrhizal fungi. Sydowia 57, 166-178. 
Carr AF. 1952 - Handbook of Turtles: The Turtles of the United Staits, Canada and Baja California. Comstock Publishing Associates, Ithaca, NY.

Chan-ard T, Thirakhupt K, van Dijk PP. 1996 - Observations on Manouria impressa at Phu Luang Wildlife Sanctuary, Northeastern Thailand. Chelonian Conservation and Biology 2, 109-113.

Chessman BC. 1984 - Food of the snake-necked turtle, Chelodina longicollis (Shaw) (Testudines: Chelidae) in the Murray Valley, Victoria and New South Wales. Wildlife Research 11, 573578.

Chin K. 2007 - The paleobiological implications of herbivorous dinosaur coprolites from the Upper Cretaceous Two Medicine Formation of Montana: why eat wood?. Palaios 22, 554-566.

Chin K, Feldmann RM, Tashman JN. 2017 - Consumption of crustaceans by megaherbivorous dinosaurs: dietary flexibility and dinosaur life history strategies. Scientific reports 7, 11163.

Claridge AW, May TW. 1994 - Mycophagy among Australian mammals. Australian Journal of Ecology 19, 251-275.

Claridge AW, Tanton MT, Seebeck JH, Cork SJ, Cunningham RB. 1992 - Establishment of ectomycorrhizae on the roots of two species of Eucalyptus from fungal spores contained in the faeces of the long-nosed potoroo (Potorous tridactylus). Austral Ecology 17, 207-217.

Claridge AW, Trappe JM. 2005 - Sporocarp mycophagy: nutritional, behavioral, evolutionary and physiological aspects. In: The Fungal Community-Its Organization and Role in the Ecosystem, pp. 599-611. Taylor and Francis, Boca Raton, FL, USA.

Cobo M, Andreu AC. 1988 - Seed consumption and dispersal by the spur-thighed tortoise Testudo graeca. Oikos 51, 267-273.

Colgan W, Claridge AW. 2002 - Mycorrhizal effectiveness of Rhizopogon spores recovered from faecal pellets of small forest-dwelling mammals. Mycological Research 106, 314-320.

Comport SS, Hume ID. 1998 - Gut morphology and rate of passage of fungal spores through the gut of a tropical rodent, the giant white-tailed rat (Uromys caudimaculatus). Australian Journal of Zoology 46, 461-471.

Conant R. 1938 - The reptiles of Ohio. American Midland Naturalist 20, 1-200.

Cooper Jr WE, Vitt LJ. 1989 - Prey odor discrimination by the broad-headed skink (Eumeces laticeps). Journal of Experimental Zoology 249, 11-16.

Cooper T, Vernes K. 2011 - Mycophagy in the larger bodied skinks of the genera Tiliqua and Egernia: are there implications for ecosystem health?. Australian Zoologist 35, 681-684.

Cork SJ, Kenagy GJ. 1989a - Nutritional value of hypogeous fungus for a forest-dwelling ground squirrel. Ecology 70, 577-586.

Cork SJ, Kenagy GJ. 1989b - Rates of gut passage and retention of hypogeous fungal spores in two forest-dwelling rodents. Journal of Mammalogy 70, 512-519.

Creaser EP. 1940 - A note on the food of the box turtle. Copeia 2, 131.

Danks MA. 2011 - The swamp wallaby Wallabia bicolor: a generalist browser as a key mycophagist. (Unpublished PhD Dissertation University of New England).

Danks MA. 2012 - Gut-retention time in mycophagous mammals: a review and a study of trufflelike fungal spore retention in the swamp wallaby. Fungal Ecology 5, 200-210.

Das KC, Gupta A. 2015 - New distribution records of tortoises (Chelonia: Testudinidae) from Barak Valley, Assam, northeastern india with notes on ecology and vernacular traditional taxonomy. Journal of Threatened Taxa 7, 7017-7023.

Deepak V. 2011 - Ecology and Behaviour of Travancore Tortoise (Indotestudo travancorica) In Anamalai Hills, Western Ghats. PhD dissertation, Saurashtra University.

Deepak V. 2015 - Nature watch. Resonance 20, 47-54.

Dell J, Chapman A. 1979 - Reptiles and frogs of wilroy Nature Reserve. Biological survey of the Western Australian wheatbelt Part 8, 1-54.

Del Vecchio S, Burke RL, Rugiero L, Capula M, Luiselli L. 2011 - The turtle is in the details: microhabitat choice by Testudo hermanni is based on microscale plant distribution. Animal Biology 61, 249-261. 
Dolbeer RA. 1969 - A study of population density, seasonal movements and weight changes, and winter behavior of the eastern box turtle, Terrapene c. carolina L., in eastern Tennessee. MS thesis, The University of Tennessee.

Elliott TF, Elliott K. 2019 - Vertebrate consumption and dispersal of the Nothofagaceae associated ascomycete Cyttaria. Austral Ecology 44, 747-751.

Elliott TF, Jusino MA, Trappe JM, Lepp H, Ballard G, Bruhl JJ, Vernes K. 2019a - A global review of the ecological significance of symbiotic associations between birds and fungi. Fungal Diversity 98, 161-194.

Elliott TF, Truong C, Séné O, Henkel TW. 2019b - Animal-fungal Interactions 3: First Report of Mycophagy by the African Brush-tailed Porcupine Atherurus africanus Gray, 1842 (Mammalia: Rodentia: Hystricidae). Journal of Threatened Taxa. 11, 13415-13418.

Elliott TF, Vernes K. 2019 - Superb Lyrebird Mycophagy, Truffles, and Soil Disturbance. Ibis 161, 198-204.

Elliott TF, Stephenson SL. 2018 - Mushrooms of the southeast. Portland, Oregon: Timber Press. $407 \mathrm{p}$.

Elliott TF, Trappe JM, Türkoğlu A. 2018 - Animal-fungal Interactions 2: First Report of Mycophagy by the Eastern European Hedgehog, Erinaceus concolor Martin, 1837 (Mammalia: Eulipotyphla: Erinaceidae). Journal of Threatened Taxa 10, 12277-12279.

Elliott TF, Trappe JM. 2018 - A worldwide nomenclature revision of sequestrate Russula species. Fungal Systematics and Evolution 1, 229-242.

Elliott TF, Marshall PA. 2016 - Animal-Fungal Interactions 1: Notes on Bowerbird's Use of Fungi. Australian Zoologist 38, 59-61.

Espenshade WH, Buskirk J. 1994 - Manouria impressa (Günther 1882): A Summary of Known \& Anecdotal Information. Tortuga Gazette 30, 1-5.

Espenshade III WH, Duc LT. 2000 - Pu Mat turtle hunter interview. Turtle and Tortoise Newsletter $5,16-19$

Field DJ, Gauthier JA, King BL, Pisani D et al. 2014 - Toward consilience in reptile phylogeny: miRNAs support an archosaur, not lepidosaur, affinity for turtles. Evolution \& development 16, 189-196.

Fisher MC, Garner TW, Walker SF. 2009 - Global emergence of Batrachochytrium dendrobatidis and amphibian chytridiomycosis in space, time, and host. Annual review of microbiology 63, 291-310.

Fitch HS. 1963 - Natural history of the black rat snake (Elaphe o. obsoleta) in Kansas. Copeia 4, 649-658.

Fitzgerald KT, Newquist KL. 2008 - Poisonings in reptiles. Veterinary Clinics of North America: Exotic Animal Practice 11, 327-357.

Fleckenstein LJ, Agha M, Price SJ. 2015 - Terrapene carolina (Eastern Box Turtle). Diet. Herpetological Review 46, 1.

Fogel R, Trappe JM. 1978 - Fungus consumption (mycophagy) by small mammals. Northwest Science 52, 1-31.

Galante TE, Horton TR, Swaney DP. 2011 - 95\% of basidiospores fall within $1 \mathrm{~m}$ of the cap: a field-and modeling-based study. Mycologia 103, 1175-1183.

Gehring CA, Wolf JE, Theimer TC. 2002 - Terrestrial vertebrates promote arbuscular mycorrhizal fungal diversity and inoculum potential in a rain forest soil. Ecology Letters 5, 540-548.

Ghosh P, Bhattacharya SK, Sahni A, Kar RK et al. 2003 - Dinosaur coprolites from the Late Cretaceous (Maastrichtian) Lameta Formation of India: isotopic and other markers suggesting a C3plant diet. Cretaceous Research 24, 743-750.

Gibson RC, Buley KR. 2004 - Biology, captive husbandry, and conservation of the malagasy flattailed tortoise, Pyxis planicauda Grandidier, 1867. Herpetological Review 35, 111.

Glaw F, Vences M. 2007 - A Field Guide to the Amphibians and Reptiles of Madagascar. Vences \& Glaw Verlags GbR, Cologne, Germany, 495 pg. 
Goetz M. 2007 - Husbandry and Breeding of the Spiny Turtle Heosemys spinosa (GRAY, 1931) at the Durrell Wildlife Conservation Trust. Radiata 16, 2-15.

Gregory JB, Lucas AHS. 1886 - To Wilson's Promontory Overland. Part 4. Victorian Naturalist 2, $150-154$.

Gregory PT, Macartney JM, Rivard DH. 1980 - Small mammal predation and prey handling behavior by the garter snake Thamnophis elegans. Herpetologica 36, 87-93.

Günther A. 1867 - Additions to the knowledge of Australian reptiles and fishes. Annals and Magazine of Natural History 3, 45-68.

Guzmán A, Stevenson PR. 2008 - Seed dispersal, habitat selection and movement patterns in the Amazonian tortoise, Geochelone denticulata. Amphibia-Reptilia 29, 463-472.

Hailey A, Coulson IM. 1996 - Nesting behaviour and clutch and egg size of the hingeback tortoise Kinixys spekii. British Herpetological Society Bulletin 58, 11-18.

Hailey A, Coulson IM, Chidavaenzi RL. 1997 - Fungus eating by the African tortoise Kinixys spekii. Journal of Tropical Ecology 13, 469-474.

Hailey A, Coulson IM, Mwabvu T. 2001 - Invertebrate prey and predatory behaviour of the omnivorous African tortoise Kinixys spekii. African Journal of Ecology 39, 10-17.

Hailey A, Chidavaenzi RL, Loveridge JP. 1998 - Diet mixing in the omnivorous tortoise Kinixys spekii. Functional Ecology 12, 373-385.

Hailey A. 1998 - The specific dynamic action of the omnivorous tortoise Kinixys spekii in relation to diet, feeding pattern, and gut passage. Physiological zoology 71, 57-66.

Hansen RM, Johnson MK, Van Devender TR. 1976 - Foods of the desert tortoise, Gopherus agassizii, in Arizona and Utah. Herpetologica 32, 247-251.

Heiss E, Natchev N, Schwaha T, Salaberger D et al. 2011 - Oropharyngeal morphology in the basal tortoise Manouria emys emys with comments on form and function of the testudinid tongue. Journal of morphology 272, 1217-1229.

Högberg P, Piearce GD. 1986 - Mycorrhizas in Zambian trees in relation to host taxonomy, vegetation type and successional patterns. The Journal of Ecology 74, 775-785.

Horton TR. 2017 - Spore Dispersal in Ectomycorrhizal Fungi at Fine and Regional Scales. In Biogeography of Mycorrhizal Symbiosis (pp. 61-78). Springer, Cham.

Horton TR, Swaney DP, Galante TE. 2013 - Dispersal of ectomycorrhizal basidiospores: the long and short of it. Mycologia 105, 1623-1626.

Hussain G, Al-Ruqaie IM. 1999 - Occurrence, chemical composition, and nutritional value of truffles: an overview. Pakistan Journal of Biological Science 2, 510-514.

Hyett J. 1961 - A Bushman's Harvest. F.W. Cheshire Pty Ltd. Melbourne, Australia. 169 pg.

Ihlow F, Geissler P, Sovath S, Handschuh M, Böhme W. 2012 - Observations on the feeding ecology of Indotestudo elongata (Blyth, 1853) in the wild in Cambodia and Vietnam. Herpetol Notes 5, 5-7.

Jerozolimski A, Ribeiro MBN, Martins M. 2009 - Are tortoises important seed dispersers in Amazonian forests?. Oecologia 161, 517-528.

Ji-Chao W, Shi-Ping G, Hai-Tao S, Yu-Xiang L, Er-Mi Z. 2011 - Reproduction and nesting of the endangered keeled box turtle (Cuora mouhotii) on Hainan Island, China. Chelonian Conservation and Biology 10, 159-164.

Jones SC, Jordan WJ, Meiners SJ, Miller AN, Methven AS. 2007 - Fungal spore dispersal by the Eastern box turtle (Terrapene carolina carolina). The American Midland Naturalist 157, 121-126.

Jones MT, Sievert PR. 2009 - Glyptemys insculpta (Wood Turtle). Diet. Herpetological Review 40, 433-434

Jordan WJ. 2004 - Eastern Box Turtle (Terrapene c. carolina) as a Dispersal Vector of Seeds and Spores. MS. Thesis, Eastern Illinois University.

Joshua QI. 2008 - Seasonal effects on the feeding ecology and habitat of Chersina angulata in the South Western Cape. PhD dissertation, University of the Western Cape. 
Kalač P. 2009 - Chemical composition and nutritional value of European species of wild growing mushrooms: A review. Food Chemistry 113, 9-16.

Kar RK, Sharma N, Kar R. 2004 - Occurrence of fossil fungi in dinosaur dung and its implication on food habit. Current Science 87, 1053-1056.

Kennett R, Tory O. 1996 - Diet of two freshwater turtles, Chelodina rugosa and Elseya dentata (Testudines: Chelidae) from the wet-dry tropics of northern Australia. Copeia 2, 409-419.

Kershaw JA. 1927 - Victorian reptiles. Victorian Naturalist 43, 335-344.

Koenig J, Shine R, Shea G. 2001 - The ecology of an Australian reptile icon: how do blue-tongued lizards (Tiliqua scincoides) survive in suburbia?. Wildlife Research 28, 214-227.

Kotter MM, Farentinos RC. 1984 - Formation of ponderosa pine ectomycorrhizae after inoculation with feces of tassel-eared squirrels. Mycologia 76, 758-760.

Kratzing JE. 1975 - The fine structure of the olfactory and vomeronasal organs of a lizard (Tiliqua scincoides scincoides). Cell and Tissue Research 156, 239-252.

Kreisel H. 1962 - Die Lycoperdaceae der Deutschen Demokratischen Republik. Feddes Repertorium 64, 89-201.

Kuchling G. 1986 - Biology of Kinixys belliana at Nosy Faly, Madagascar. 435-440. In: Studies in Herpetology, Rocek Z. (ed.). Charles University, Prague, 754.

Lambiris AJL, Lambiris JC, Mather SA. 1989 - Observations on Speke's hinged tortoise, Kinixys spekii Gray (Chelonii: Testudinidae). The Journal of the Herpetological Association of Africa 36, 68-71.

Lamont BB, Ralph CS, Christensen PE. 1985 - Mycophagous marsupials as dispersal agents for ectomycorrhizal fungi on Eucalyptus calophylla and Gastrolobium bilobum. New Phytologist 101, 651-656.

Latham R. 1916 - Notes on Cistudo carolina from Orient, Long Island. Copeia 34, 65-67.

Lenin J. 2006 - Vijaya, India’s first woman herpetologist. Indian Ocean Turtle Newsletter 4, 2932.

Liu H, Platt SG, Borg CK. 2004 - Seed dispersal by the Florida box turtle (Terrapene carolina bauri) in pine rockland forests of the lower Florida Keys, United States. Oecologia 138, 539546.

Lodge TM, Elliott TF, Henkel TW. 2016 - Chelonoidis denticulata (Yellow-Footed Tortoise) Diet. Herpetological Review 47, 443.

Longley G. 1944 - A note on the Shingle Back Lizard (Trachysaurus rugosus). Proceedings of the Royal Zoological Society of New South Wales 1943-33, 20.

Loveridge A, Williams EE. 1957 - Revision of the African tortoises and turtles of the suborder Cryptodira. Bulletin of the Museum of Comparative Zoology, Harvard 115, 163-557.

Loveridge A. 1923 - 45. Notes on East African Tortoises collected 1921-1923, with the description of a new species of Soft Land Tortoise. Proceedings of the Zoological Society of London 93, 923-933.

Lucas AHS, Frost C. 1893 - The lizards indigenous to Victoria. Proceedings of the Royal Society of Victoria 6, 24-92.

Lucas AHS, le Souef D. 1909 - The animals of Australia - mammals, reptiles and amphibians. Whitecombe \& Tombs.

Luiselli L. 2003 - Seasonal activity patterns and diet divergence of three sympatric Afrotropical tortoise species (genus Kinixys). Contributions to Zoology 72, 211-220.

Luiselli L. 2006 - Food niche overlap between sympatric potential competitors increases with habitat alteration at different trophic levels in rain-forest reptiles (omnivorous tortoises and carnivorous vipers). Journal of Tropical Ecology 22, 695-704.

Luiselli L, Akani GC, Ebere N, Rugiero L, Vignoli L, Angelici FM, Eniang EA, Behangana M. 2011 - Food habits of a pelomedusid turtle, Pelomedusa subrufa, in tropical Africa (Nigeria): the effects of sex, body size, season, and site. Chelonian Conservation and Biology 10, 138144. 
Lunney D, Ashby E, Grigg J, Oconnell M. 1989 - Diets of Scincid Lizards Lampropholis guichenoti (Dumeril and Bibron) and Lampropholis delicata (De Vis) in Mumbulla State Forest on the South Coast of New-South-Wales. Wildlife Research 16, 307-312.

MacDonald LA, Mushinsky HR. 1988 - Foraging ecology of the gopher tortoise, Gopherus polyphemus, in a sandhill habitat. Herpetologica 44, 345-353.

Mafli A, Wakamatsu K, Roulin A. 2011 - Melanin-based coloration predicts aggressiveness and boldness in captive eastern Hermann's tortoises. Animal Behaviour 81, 859-863.

Martel A, Spitzen-van der Sluijs A, Blooi M, Bert W, Ducatelle R, Fisher MC, Woeltjes A, Bosman W, Chiers K, Bossuyt F, Pasmans F. 2013 - Batrachochytrium salamandrivorans sp. nov. causes lethal chytridiomycosis in amphibians. Proceedings of the National Academy of Sciences 110, 15325-15329.

Maser C, Trappe JM, Nussbaum RA. 1978 - Fungal-small mammal interrelationships with emphasis on Oregon coniferous forests. Ecology 59, 799-809.

Meek R. 2010 - Nutritional selection in Hermann's tortoise, Testudo hermanni, in Montenegro and Croatia. Testudo 7, 88-95.

Meurant G. 2012 - Insect-fungus interactions (Vol. 14). Academic Press.

Mifsud DA, Stapleton MM. 2014 - Kinixys conservation blueprint: a comprehensive assessment to ensure the future of the genus. Herpetological Resource and Management, Technical Publication 2014, 134 pp.

Moll D, Jansen KP. 1995 - Evidence for a role in seed dispersal by two tropical herbivorous turtles. Biotropica 27, 121-127.

Moll EO. 1989 - Indotestudo forstenii Travancore Tortoise. In: Swingland IR, Klemens MK (Eds.): The Conservation Biology of Tortoises. Occas. Pap. IUCN Species Survival Commission, No. 5. IUCN Publ., Gland, Switzerland: 118

Money NP. 1998 - More g's than the Space Shuttle: ballistospore discharge. Mycologia 90, 547558.

Morrow Jr RB. 2008 - Effects of meal size, meal composition, diel cycle, and season on oxygen consumption in the Ornate Box Turtle, Terrapene ornata ornata. MS thesis, Emporia State University.

Moskovits DK, Bjorndal KA. 1990 - Diet and food preferences of the tortoises Geochelone carbonaria and G. denticulata in northwestern Brazil. Herpetologica 46, 207-218.

Murphy JC, Henderson RW. 1997 - Tales of giant snakes: a historical natural history of anacondas and pythons. Malabar: Krieger Publishing Company.

Mwamba CK. 1995 - Effect of root-inhabiting fungi on root growth potential of Uapaca kirkiana (Muell. Arg.) seedlings. Applied Soil Ecology 2, 217-226.

Nichols JT. 1917 - Stray notes on Terrapene carolina. Copeia 46, 66-68.

Nuñez MA, Hayward J, Horton TR, Amico GC et al. 2013 - Exotic mammals disperse exotic fungi that promote invasion by exotic trees. PLoS one 8, e66832.

Nuske SJ, Vernes K, May TW, Claridge AW et al. 2017 - Redundancy among mammalian fungal dispersers and the importance of declining specialists. Fungal Ecology 27, 1-13.

Ori F, Trappe J, Leonardi M, Iotti M, Pacioni G. 2018 - Crested porcupines (Hystrix cristata): mycophagist spore dispersers of the ectomycorrhizal truffle Tuber aestivum. Mycorrhiza 28, $1-5$.

Peay KG, Kennedy PG, Bruns TD. 2008 - Fungal community ecology: a hybrid beast with a molecular master. AIBs Bulletin 58, 799-810.

Pedrono M, Smith LL. 2003 - Testudinae, land tortoises, 951-956, in: Goodman SM, Benstead, J.P. (eds.): The Natural History of Madagascar. The Univeristy of Chicago Press, Chicago and London, 1709 pp.

Pedrono M, Smith LL. 2013 - Overview of the natural history of Madagascar's endemic tortoises and freshwater turtles: Essential components for effective conservation. In: Castellano CM, Rhodin GJ, Ogle M, Mittermeier RA, Randriamahazo H, Hudson R, Lewis RE (Eds): Turtles on the Brink in Madagascar: Proceedings of Two Workshops on the Status, Conservation, 
and Biology of Malagasy Tortoises and Freshwater Turtles. Chelonian Research Monographs. Vol. 6. Pg. 59-66.

Peterson CC. 1996 - Anhomeostasis: seasonal water and solute relations in two populations of the desert tortoise (Gopherus agassizii) during chronic drought. Physiological Zoology 69, 13241358.

Piattoni F, Amicucci A, Iotti M, Ori F et al. 2014 - Viability and morphology of Tuber aestivum spores after passage through the gut of Sus scrofa. Fungal Ecology 9, 52-60.

Platt SG, Kalyar, Ko WK, Myo KM, Khaing LL, Rainwater T. 2007 - Notes on the occurrence, natural history and conservation status of turtles in Central Rakhine (Arakan) State, Myanmar. Hamadryad 31, 202-211.

Platt SG, Khaing ST, Ko WK, Kalyar 2001 - A Tortoise survey of Shwe Settaw Wildlife Sanctuary, Myanmar, with notes on the ecology of Geochelone platynota and Indotestudo elongata. Chelonian Conservation and Biology 4, 172-177.

Pough FH. 1973 - Lizard energetics and diet. Ecology 54, 837-844.

Power JH. 1926 - On the herpetological fauna of the Lobatsi-Linokana area Part 1. Transactions of the Royal Society of South Africa 14, 405-422.

Pringle A, Adams RI, Cross HB, Bruns TD. 2009 - The ectomycorrhizal fungus Amanita phalloides was introduced and is expanding its range on the west coast of North America. Molecular Ecology 18, 817-833.

Rose FL. 1988 - Thermal Preferentia of Berlandier's Tortoise (Gopherus berlandieri) and the Ornate Box Turtle (Terrapene ornata). The Southwestern Naturalist 33, 357-361.

Rozylowicz L, Dobre M. 2010 - Assessing the threatened status of Testudo hermanni boettgeri Mojsisovics, 1889 (Reptilia: Testudines: Testudinidae) population from Romania. NorthWestern Journal of Zoology 6, 190-202.

Rust RW, Roth RR. 1981 - Seed production and seedling establishment in the mayapple, Podophyllum peltatum L. American Midland Naturalist 105, 51-60.

Scheele BC, Pasmans F, Skerratt LF, Berger L, Martel A, Beukema W, Acevedo AA, Burrowes, PA, Carvalho T, Catenazzi A, De la Riva I. 2019 - Amphibian fungal panzootic causes catastrophic and ongoing loss of biodiversity. Science 363, 1459-1463.

Schulz M, Eyre R. 1997 - Observations of some reptiles from Minnie Water, north-eastern New South Wales. Herpetofauna 27, 41-42.

Serventy V. 1970 - Dryandra: the story of an Australian forest. Sydney: AH \& AW Reed.

Shea G. 2006 - Diet of two species of bluetongue skink, Tiliqua multifasciata and Tiliqua occipitalis (Squamata: Scincidae). Australian Zoologist 33, 359-368.

Shea G. 1999 - Morphology and natural history of the land mullet Egernia major (Squamata: Scincidae). Australian Zoologist 31, 351-364.

Shea GM. 1989 - Diet and reproductive biology of the Rottnest Island bobtail, Tiliqua rugosa konowi (Lacertilia, Scincidae). Herpetological Journal 1, 366-369.

Shine R, Covacevich J. 1983 - Ecology of highly venomous snakes: the Australian genus Oxyuranus (Elapidae). Journal of Herpetology 17, 60-69.

Simpson JA. 1998 - Why don't more birds eat more fungi? Australasian Mycological Newsletter 17, 67-68.

Simpson JA. 2000 - More on mycophagous birds. Australasian Mycologist 19, 49-51.

Sitha S, Yoeung S, Chamnan K, Sokhorn K, Kagna C. 2006 - Extending Chelonian Research, Education and Conservation in Southwest Cambodia. Final Report December 2006. Pg 106.

Slip DJ, Shine R. 1988 - Feeding habits of the diamond python, Morelia s. spilota: ambush predation by a Boid snake. Journal of Herpetology 22, 323-330.

Smith SE, Read DJ. 2008 - Mycorrhizal Symbiosis. London: Academic Press.

Smith HM. 1956 - Handbook of amphibians and reptiles of Kansas (Vol. 9). Lawrence: University of Kansas. 1-336.

Smith PW. 1961 - The amphibians and reptiles of Illinois. Illinois Natural History Survey Bulletin 28, 1-297. 
Sriprateep K, Aranyavalai V, Aowphol A, Thirakhupt K. 2013 - Population structure and reproduction of the elongated tortoise Indotestudo elongata (Blyth, 1853) at Ban Kok Village, Northeastern Thailand. Tropical Natural History 13, 21-37.

Stickel LF. 1950 - Populations and home range relationships of the box turtle, Terrapene $c$. carolina (Linnaeus). Ecological Monographs 20, 351-378.

Strang CA. 1983 - Spatial and temporal activity patterns in two terrestrial turtles. Journal of Herpetology 17, 43-47.

Surface HA. 1908 - First report on the economic features of turtles of Pennsylvania. Zoological Bulletin of the Division of the Pennsylvania Department of Agriculture 6, 105-195.

Sweeten SE. 2008 - Home range, hibernacula fidelity, and best management practices for Wood Turtles (Glyptemys insculpta) in Virginia. MS thesis, James Madison University, Harrisonburg, Virginia.

Takashi ODA, Tanaka C, Tsuda M. 2004 - Molecular phylogeny and biogeography of the widely distributed Amanita species, A. muscaria and A. pantherina. Mycological Research 108, 885896.

Tedersoo L, May TW, Smith ME. 2010 - Ectomycorrhizal lifestyle in fungi: global diversity, distribution, and evolution of phylogenetic lineages. Mycorrhiza 20, 217-263.

Toledo LF, Prado CPA, Andrade DV. 2004 - Tupinambis merianae (Tegu Lizard) Fungivory. Herpetological Review 35, 173-174.

Trappe JM, Maser C. 1976 - Germination of spores of Glomus macrocarpus (Endogonaceae) after passage through a rodent digestive tract. Mycologia 68, 433-436.

van Dijk PP. 1998 - The Natural History of the Elongated Tortoise, Indotestudo elongata (Blyth, 1853) in a Hill Forest Mosaic in Western Thailand, With Notes on Sympatric Turtle Species. PhD Dissertation. National University of Ireland, Galway.

Valencia-Aguilar A, Cortés-Gómez AM, Ruiz-Agudelo CA. 2013 - Ecosystem services provided by amphibians and reptiles in Neotropical ecosystems. International Journal of Biodiversity Science, Ecosystem Services \& Management 9, 257-272.

Varela RO, Bucher EH. 2002 - Seed dispersal by Chelonoidis chilensis in the Chaco dry woodland of Argentina. Journal of Herpetology 36, 137-140.

Vasudevan K, Pandav B, Deepak V. 2010 - Ecology of two endemic turtles in the Western Ghats (p. 2). Final Technical Report, Wildlife Institute of India 74p.

Veerappan D, Vasudevan K. 2012 - Feeding ecology of the Travancore tortoise (Indotestudo travancorica) in the Anamalais, Western Ghats, India. Herpetology Notes 5, 203-209

Vijaya J. 1983 - The Travancore tortoise, Geochelone travancorica. Hamadryad 8, 11-13.

Vitt LJ, Cooper Jr WE. 1986 - Foraging and diet of a diurnal predator (Eumeces laticeps) feeding on hidden prey. Journal of Herpetology 20, 408-415.

Vogilino P. 1895 - Richerche intorno all' azione delle lumache e dei rospi nello sviluppo di Agaricini. Nuovo Giornale Botanico 27, 181-185.

Vogt KA, Edmonds RL, Grier CC. 1981 - Biomass and nutrient concentrations of sporocarps produced by mycorrhizal and decomposer fungi in Abies amabilis stands. Oecologia 50, 170175

Waite ER. 1925 - Field notes on some Australian reptiles and a batrachian. Hassell Press.

Walde AD, Bider JR, Daigle C, Masse D et al. 2003 - Ecological aspects of a wood turtle, Glyptemys insculpta, population at the northern limit of its range in Quebec. The Canadian Field-Naturalist 117, 377-388.

Wallis IR, Claridge AW, Trappe JM. 2012 - Nitrogen content, amino acid composition and digestibility of fungi from a nutritional perspective in animal mycophagy. Fungal Biology 116, 590-602.

Wanchai P. 2012 - Radio-telemetry study of home range size and activities of the impressed tortoise, Manouria impressa (Gunther, 1882) (Doctoral dissertation, Chulalongkorn University). 
Wanchai P, Stanford CB, Pradatsundarasar AO, Tharapoom K, Thirakhupt K. 2013 - Activity Budget of the Impressed Tortoise, Manouria impressa (Günther, 1882), in Phu Luang Wildlife Sanctuary, Thailand. Tropical Natural History 13, 39-48.

Wanchai P, Stanford CB, Thirakhupt K, Thanhikorn S. 2012 - Home Range of the Impressed Tortoise, Manouria impressa Günther, 1882) at Phu Luang Wildlife Sanctuary, Loei Province, Thailand. Tropical Natural History 12, 165-174.

Wang E, Donatti CI, Ferreira VL, Raizer J, Himmelstein J. 2011 - Food habits and notes on the biology of Chelonoidis carbonaria (Spix 1824) (Testudinidae, Chelonia) in the southern Pantanal, Brazil. South American Journal of Herpetology 6, 11-19.

Webb GA, Simpson JA. 1985 - Some unusual food items for the southern blotched blue-tongue lizard Tiliqua nigrolutea (Quoy and Gaimard) at Bombala, New South Wales. Herpetofauna $16,44-49$.

Webster H. 1902 - Certain eaters of mushrooms. Rhodora 4(40), 77-79.

Weiss JA. 2009 - Demographics, activity, and habitat selection of the Eastern Box Turtle (Terrapene c. carolina) in West Virginia. Masters Thesis, Graduate College Marshall University.

Whitaker N, Vijaya J. 2009 - Biology of the forest cane turtle, Vijayachelys silvatica, in South India. Chelonian Conservation and Biology 8, 109-115.

Wolcott GN. 1924 - The food of Porto Rican lizards. Journal of the Department of Agriculture of Porto Rico 7, 5-37

Wolfe BE, Richard F, Cross HB, Pringle A. 2010 - Distribution and abundance of the introduced ectomycorrhizal fungus Amanita phalloides in North America. New Phytologist 185, 803816.

Worthington RJ, Sievers ER, Ligon DB, Lago PK. 2017 - Insect (Arthropoda: Insecta) Composition in the Diet of Ornate Box Turtles (Terrapene ornata ornata) in Two Western Illinois Sand Prairies, with a New State Record for Cyclocephala (Coleoptera: Scarabaeidae). The Great Lakes Entomologist 50, 61-67.

Wright J. 1892 - Notes on the Food of the Box Tortoise. Science 19(471), 95.

Xiao F, Wang J, Long Z, Shi H. 2017 - Diet of Two Endangered Box Turtles (Cuora spp.) on Hainan Island, China. Chelonian Conservation and Biology 16, 236-238. 